\title{
Studies on Correlation and Path Analysis in Linseed (Linum usitatissimum L.) Over Locations in Mid-hills of North-Western Himalayas
}

\begin{abstract}
Background: Seed yield is a very important trait for selection but shows low heritability and hence is difficult to improve. Since the productivity of linseed (Linum usitatissimum L.) in India as well as Himachal Pradesh is low in comparison to other major linseed growing countries and states, improvement in cultivars for grain yield is a must. Therefore, the present study was aimed for studying the character associations in linseed genotypes for seed yield over locations.

Method: The experiment was conducted during rabi 2019-2020. The experimental material for the present investigation comprised of 52 linseed genotypes grown over three locations in Himachal Pradesh i.e. Linseed Experimental Farm, CSK HPKV, Palampur (1290 $\mathrm{m}$ amsl), Shivalik Agricultural Research and Extension Centre, Kangra (700 m amsl) and Hill Agricultural Research and Extension Centre, Dhaulakuan (468 m amsl). Randomized block design with three replications was used. Phenotypic and genotypic correlation coefficients were worked out as per the procedure outlined by Burton and De Vane (1953) and Johnson et al. (1955). Direct and indirect effects of component traits on grain yield were worked out using correlation coefficient of various traits as suggested by Wright (1921) and elaborated by Dewey and Lu (1959).

Result: Correlation studies indicated highly significant positive correlation for seed yield with 1000 seed weight $\left(0.965^{* \star}\right)$ followed by harvest index $\left(0.801^{* *}\right)$, secondary branches $\left(0.585^{* *}\right)$ and a significant correlation with biological yield $\left(0.269^{* *}\right)$. Seed yield exhibited a non-significant positive correlation with seeds per capsule. However, a negative significant correlation was observed for seed yield with days to 50 per cent flowering and number of primary branches. The path coefficient analysis indicated that 1000 seed weight exhibited maximum positive direct effect with seed yield $(0.741)$ while others had a low direct effect. The significant positive correlation of number of secondary branches and harvest index with seed yield was mainly due to indirect effect via 1000 seed weight indicating that 1000 seed weight is the most important trait for the improvement of grain yield in linseed as per the present study.
\end{abstract}

Key words: Correlation coefficients, Linseed, Path coefficients, Seed yield.

\section{INTRODUCTION}

Linum usitatissimum $\mathrm{L}$. is an important fibre (flax) and oilseed (linseed) plant (Milliam et al., 2005) belonging to the genus Linum and family linaceae. Linum usitatissimum is the only agriculturally important species belonging to the genus Linum. Every part of the plant has some economic use. Seeds give oil which can be used for both edible as well as non-edible purposes and stems give fibre used for making of fabric "linen". Linseed is a cool season crop but is sensitive to frost. A temperature range of $20-25^{\circ} \mathrm{C}$ is optimum for its good yield and quality. The linseed crop is suitable for low rainfall area and is generally raised where the average annual rainfall ranges from 45 to $75 \mathrm{~cm}$. In India, it is among the important non-edible oilseed crops (Bhateria et al., 2006) with major role in industrial purposes such as paints and varnishes. Despite of the wide range of benefits provided by the crop, it's productivity in India is very low $(573.62 \mathrm{~kg} / \mathrm{ha})$ in comparison to the world average of $951.83 \mathrm{~kg} / \mathrm{ha}$ (FAOSTAT 2019) because it is normally grown under rainfed situation by resource poor farmers and also, non-availability of high potential cultivars have lowered down the productivity
Department of Genetics and Plant Breeding, College of Agriculture, CSK Himachal Pradesh Krishi Vishvavidyalaya, Palampur-176 062, Himachal Pradesh, India.

Corresponding Author: Garima Thakur, Department of Genetics and Plant Breeding, College of Agriculture, CSK Himachal Pradesh Krishi Vishvavidyalaya, Palampur-176 062, Himachal Pradesh, India. Email: thakurgarima725@gmail.com

How to cite this article: Thakur, G., Paul, S., Chandel, U. and Thakur, R. (2021). Studies on Correlation and Path Analysis in Linseed (Linum usitatissimum L.) Over Locations in Mid-hills of North - Western Himalayas. Indian Journal of Agricultural Research. DOI: $10.18805 /$ IJARe.A-5863.

Submitted: 26-06-2021 Accepted: 19-10-2021 Online: 18-11-2021

of this oilseed.In Himachal Pradesh, linseed has a productivity of $375 \mathrm{~kg} / \mathrm{ha}$ (Statistical Year Book of Himachal Pradesh 2018) and is mostly grown for domestic use which is either sown on poor marginal land or is broadcasted in standing paddy crop, $15-20$ days before its harvest. 
Major basis for low productivity in India would be nonavailability of high yielding linseed varieties. This may be due to the fact that yield is a complex trait, controlled by many genes with small additive effects in self-pollinated crops. Therefore, yield shows low heritability and is a difficult trait to improve (Slinkard 2000). Hence, direct selection for high yield is non-effective. Since seed yield is an outcome of several traits interacting with one another, indirectselection through various yield components has proven more effective. This selection criterion takes into account the information on interrelationship among agronomic characters, their relationship with grain yield as well as their direct influence on grain yield (Tadesse et al. 2009). This analysis can be brought about by correlation and path studies.

Correlation and path analysis estimates the extent of association of different yield components among themselves and with the yield and also measures direct and indirect contribution of individual attributes towards seed yield (Rajanna et al. 2014). This kind of analysis further helps the breeder in outlining his selection strategies to improve grain yield. In the light of above scenario present investigation was carried out for studying the character associations in linseed genotypes for seed yield grown over locations.

\section{MATERIAL AND METHODS}

The experiment was conducted in rabi 2019-20 at three locations i.e., Linseed experimental farm, CSKHPKV Palampur (1290 m amsl), Shivalik Agricultural Research and Extension Centre, Kangra (700 m amsl) and Hill Agricultural Research and Extension Centre, Dhaulakuan (468 m amsl). The experimental material comprised of 52 genotypes (Table 1) sown in randomized block design with three replications at each location. Pooled analysis of variance was carried out as per the standard statistical methods. Phenotypic and genotypic correlation coefficients were worked out as per the procedure outlined by Burton and De Vane (1953) and Johnson et al. (1955). Direct and indirect effects of component traits on grain yield were worked out using correlation coefficient of various traits as suggested by Wright (1921) and elaborated by Dewey and Lu (1959).

Where;

$$
\begin{array}{r}
P C V=\sqrt{ } V P / \bar{X} \times 100 \\
G C V=\sqrt{ } V G / \bar{X} \times 100
\end{array}
$$

$\mathrm{VP}=$ Phenotypic variance

$\underline{\mathrm{V}} \mathrm{X}=$ Genotypic variance

$\bar{X}=$ Mean of the sample

$$
\text { Harvest index }=\frac{\text { Grain yield }}{\text { Biological yield }} \times 100
$$

\section{RESULTS AND DISCUSSION}

\section{Genetic parameters of variability}

Phenotypic coefficient of variation (PCV), genotypic coefficient of variation (GCV) and heritability in broad sense (h2bs) were estimated for characters studied and are presented in (Table 2). PCV was found highest (>20\%) for
Table 1: List of 52 linseed accessions.

Genotypes Parentage

KL-236 Jeevan $\times$ Janki

KL-241

KL-244

$\mathrm{KL}-257$

Giza-7 ×KLS-1

$\mathrm{KL}-263$

KL-269

$\mathrm{KL}-278$

KL-279

$\mathrm{KL}-280$

$\mathrm{KL}-284$

$\mathrm{KL}-285$

KL-305

KL-306

KL-307

KL-308

KL-309

$\mathrm{KL}-310$

KL-311

KL-312

$\mathrm{KL}-313$

KL-314

KL-315

KL-316

$\mathrm{KL}-317$

KL-318

KL-319

KL-320

KL-321

KL-322

KL-323

KL-324

KL-325

KL-326

KL-327

Him Alsi-2

Nagarkot

Himani

Jeewan

Baner

Bhagsu

Himalini

Him Alsi-1

Janki

Surbhi

Canada

Binwa

Giza-7

Giza-8

Belinka

K-1 Raja

JRF-4

Ayogi
(RLC $29 \times$ Jeevan) $\times$ RLC-29

LC-2323 $\times$ KLS-1

$\mathrm{KL}-223 \times \mathrm{KL}-224$

EC-21741 x LC-216

Giza-5 $\times$ Aayogi

Mariena × Giza-5

Giza-7 × Belinka

Rjeena $\times$ Him Alsi-2

Binwa $\times$ Him Alsi-2

TL-27 $\times$ Nagarkot

Nagarkot $\times$ T-397

Him Alsi-2 $\times$ Nagarkot

TL-397 $\times$ Nagarkot

Canada $\times$ Nagarkot

Giza-8 × Nagarkot

Giza-6 × Nagarkot

Giza $-7 \times$ Nagarkot

Faiking $\times$ Nagarkot

Belinka $60 \times$ Nagarkot

TL-27 $\times$ Flak-1

Him Alsi-2 $\times$ Binwa

Him Alsi-1 $\times$ Binwa

Him Alsi-2 x TL-11

(KL-243× Janki ) $\times$ KL-243

(Gaurav $\times$ Nagarkot) $\times$ Nagarkot

TL-43 $\times$ Binwa

(TL-43× Binwa) $\times$ TL-43

(KL-178 $\times$ Ariane) $\times \mathrm{KL}-178$

TL-11 $\times$ Him Alsi-2

TL-37-2 $\times$ Him Alsi-2

Binwa $\times$ Him Alsi-2

$($ Janki $\times$ TL- 43) $\times$ Janki

EC-21741 x LC-216

New River $\times$ LC -216

DPL-20 × KLS-1

Sumit $\times$ LC-216

EC-21741 x LC-214

RL-50-3 × Surbhi

K2 $\times$ Kangra Local

K2 $\times$ TLP-1

Palampur

LC-216 x LC-185

Exotic collection

Flak-1 x SPS 47/7-10-3

Exotic collection

Exotic collection

Exotic collection

CSIRO, Canberra, Australia

CRIJAF, Barrackpore

Exotic collection 
seed yield (60.91\%), followed by harvest index (58.21\%) and number of primary branches $(23.58 \%)$ and secondary branches $(23.52 \%)$ in accordance with the results of Dabola et al., 2020. The lowest PCV $(<10 \%)$ was observed for days to 50 per cent flowering (3.83\%) followed by seeds per capsule $(5.40 \%)$ and days to 75 per cent maturity (5.587). Lowest PCV for seeds/capsule was also observed by Terfa and Gurmu 2020. GCV was observed highest for seed yield per plant $(58.77 \%)$ followed by harvest index $(56.75 \%)$. The least GCV was observed for seed per capsule $(2.13 \%)$ followed by days to 50 per cent flowering (3.46\%) confirmed by Singh et al., 2015 and days to 75 per cent maturity $(5.47 \%)$. Heritability in broad sense was also estimated and it ranged from $15.66 \%$ in seeds per capsule to $95.95 \%$ in days to 75 per cent maturity. Heritability was observed high (>60\%) for most of the traits with highest for days to 75 per cent maturity (95.95\%) followed by harvest index, seed yield, 1000 seed weight, numberof secondary branches, plant height, biological yield, days to 50 per cent flowering and technical height. Genetic advance as percent of mean was observed highest for seed yield (96.383\%) followed by harvest index (94.521\%).

\section{Correlation coefficient analysis}

Phenotypic and genotypic correlation coefficients were estimated to know the degree of association among the 12 traits. In the present investigation correlation coefficient analysis depicted that genotypic and phenotypic correlation coefficient differed in their magnitude for few characters yet both phenotypic and genotypic correlation coefficients were in the same direction. However, genotypic correlation coefficients were greater than its corresponding phenotypic correlation coefficients for most of the traits. Similar results were observed by Reddy et al., 2013, Akbar et al., 2001, Sharma et al., 2016. The difference in magnitude between the genotypic and phenotypic correlation is a result of the effect of environment on the phenotype. The environmental effect may be in the same direction as the genetic effects and hence result in similarity between genotypic and phenotypic correlation (Cheverud 1984) or instead have an effect opposite to the genetic effects which results in different genotypic and phenotypic correlations.

Since genotypic correlations require large sample sizes for its appropriate estimation, phenotypic correlation coefficient can be the representative of genotypic correlation coefficient (Sodini et al., 2018). Therefore the use of phenotypic correlation as a reflection of genotypic correlation is considered appropriate in evolutionary biology. Results indicated highly significant positive correlation for seed yield with 1000 seed weight $\left(0.965^{\star \star}\right)$ followed by harvest index $\left(0.801^{\star \star}\right)$, secondary branches $\left(0.585^{\star \star}\right)$ and a significant correlation with biological yield $\left(0.269^{\star \star}\right)$ (Table 3 ) which were in accordance to the findings of Kumar and Paul 2016 and Ankit et al.2019. Positive association of 1000 seed weight with seed yield is reported earlier by Gudmewad et al. 2016, Tariq et al. 2014, Ibrar et al. 2016. It suggested that improvement for these traits can lead to improvement in grain yield under selection.

Whereas, a non-significant positive correlation was observed for seed yield with seeds per capsule which were in conformity with the findings of Kumar and Paul 2016. A negative significant association was also observed for seed yield with days to 50 per cent flowering and number of primary branches which was similar to findings of Tadesse et al. 2009. Conversely, among the other traits days to $50 \%$ flowering showed a highly positive significant correlation with plant height $\left(r_{p}=0.513^{* *}\right)$ and technical plant height $\left(0.475^{\star *}\right)$. Plant height was positively and highly significantly correlated with technical plant height $\left(r_{p}=0.883^{* *}\right)$. Significant positive correlation was also observed between technical plant height and number of primary branches $\left(r_{p}=\right.$ $\left.0.195^{\star}\right)$. Plant height and number of primary branches revealed positive significant association with biological yield $\left(r_{p}=0.209^{* *}, r_{p}=0.247^{* *}\right.$ respectively $)$. Highly significant positive correlation was also observed for harvest index with number of secondary branches $\left(r_{p}=0.597^{\star *}\right)$, biological yield $\left(r_{p}=0.354^{\star *}\right)$ and 1000 seed weight $\left(r_{p}=0.797^{* *}\right)$. Positive significant correlation of harvest index with 1000 seed weight was also observed by Patial et al. 2018. Positive correlation arises due the coupling phase of linkage of genes controlling

Table 2: Genetic parameters of variability for different yield and related traits in linseed pooled over locations.

\begin{tabular}{lcccccc}
\hline Character & Mean \pm S.E. $(\mathrm{m})$ & range & PCV & GCV & hbs & GA \\
\hline Days to $50 \%$ flowering & $122.678 \pm 1.651$ & $107-135$ & 3.836 & 3.464 & 81.532 & 6.444 \\
Days to 75\% maturity & $171.058 \pm 1.569$ & $153-183$ & 5.587 & 5.473 & 95.957 & 11.045 \\
Plant height & $89.751 \pm 2.528$ & $84.127-112.820$ & 9.157 & 8.483 & 85.810 & 16.187 \\
Technical Plant height & $63.764 \pm 2.666$ & $50.303-76.247$ & 11.639 & 10.451 & 80.635 & 19.333 \\
No. of primary branches & $6.504 \pm 0.399$ & $4.390-9.240$ & 23.589 & 22.358 & 89.831 & 43.652 \\
No. of secondary branches & $19.240 \pm 2.332$ & $13.673-30.150$ & 23.529 & 18.254 & 60.188 & 29.173 \\
Capsule/plant & $77.634 \pm 10.623$ & $56.750-100.863$ & 19.277 & 9.526 & 24.418 & 9.697 \\
Seeds/capsule & $7.865 \pm 0.319$ & $7.343-8.573$ & 5.405 & 2.139 & 15.661 & 1.744 \\
Biological yield/plant & $55.000 \pm 2.529$ & $74.600-40.577$ & 14.548 & 13.414 & 85.019 & 25.479 \\
1000 seed weight & $6.650 \pm 0.263$ & $5.150-7.927$ & 14.805 & 13.993 & 89.331 & 27.244 \\
Harvest index & $18.009 \pm 1.908$ & $5.360-34.753$ & 58.214 & 56.751 & 95.034 & 94.521 \\
Seed yield/plant & $9.192 \pm 1.202$ & $2.757-17.223$ & 60.917 & 58.775 & 93.090 & 96.383 \\
\hline
\end{tabular}




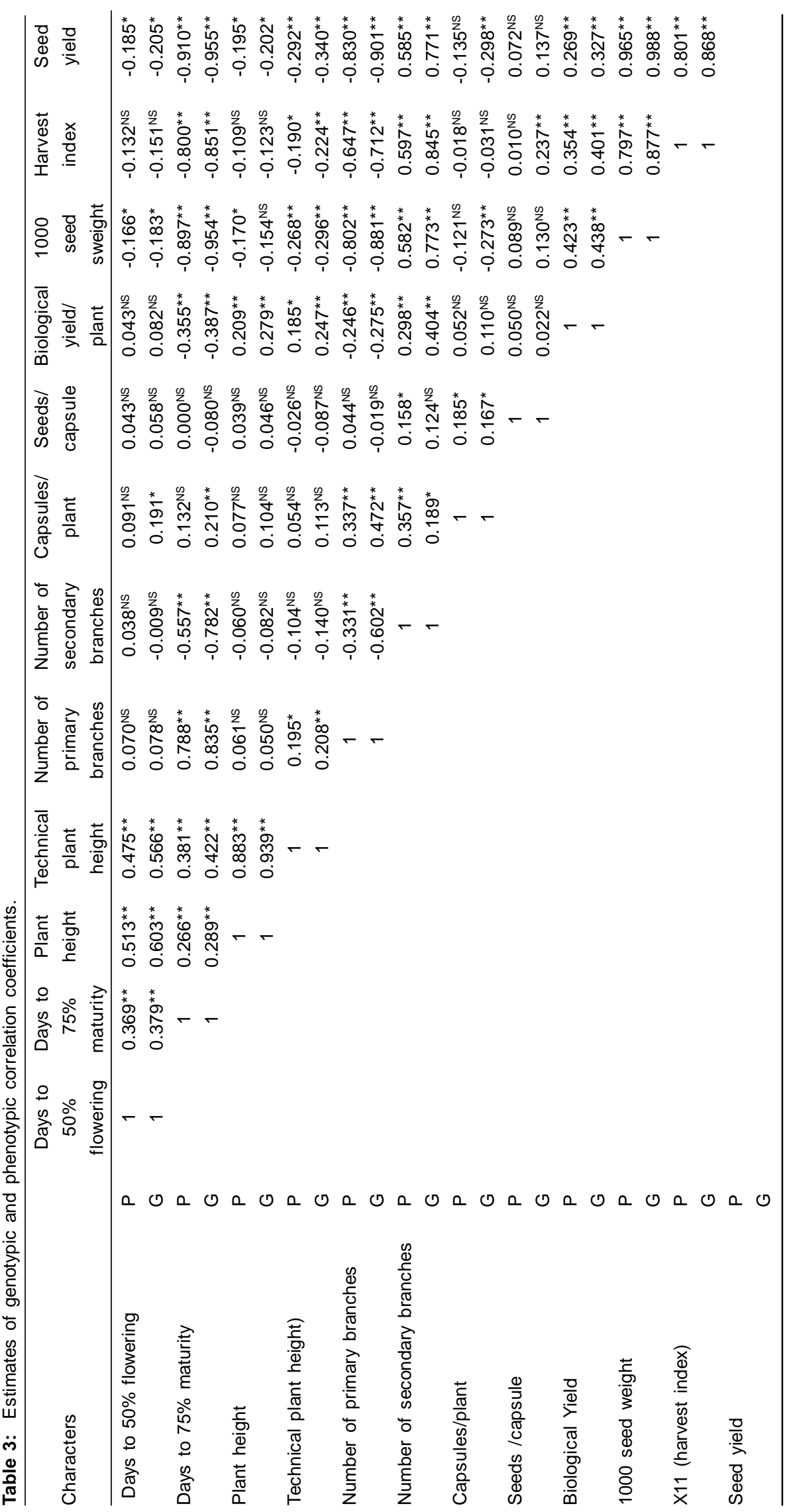




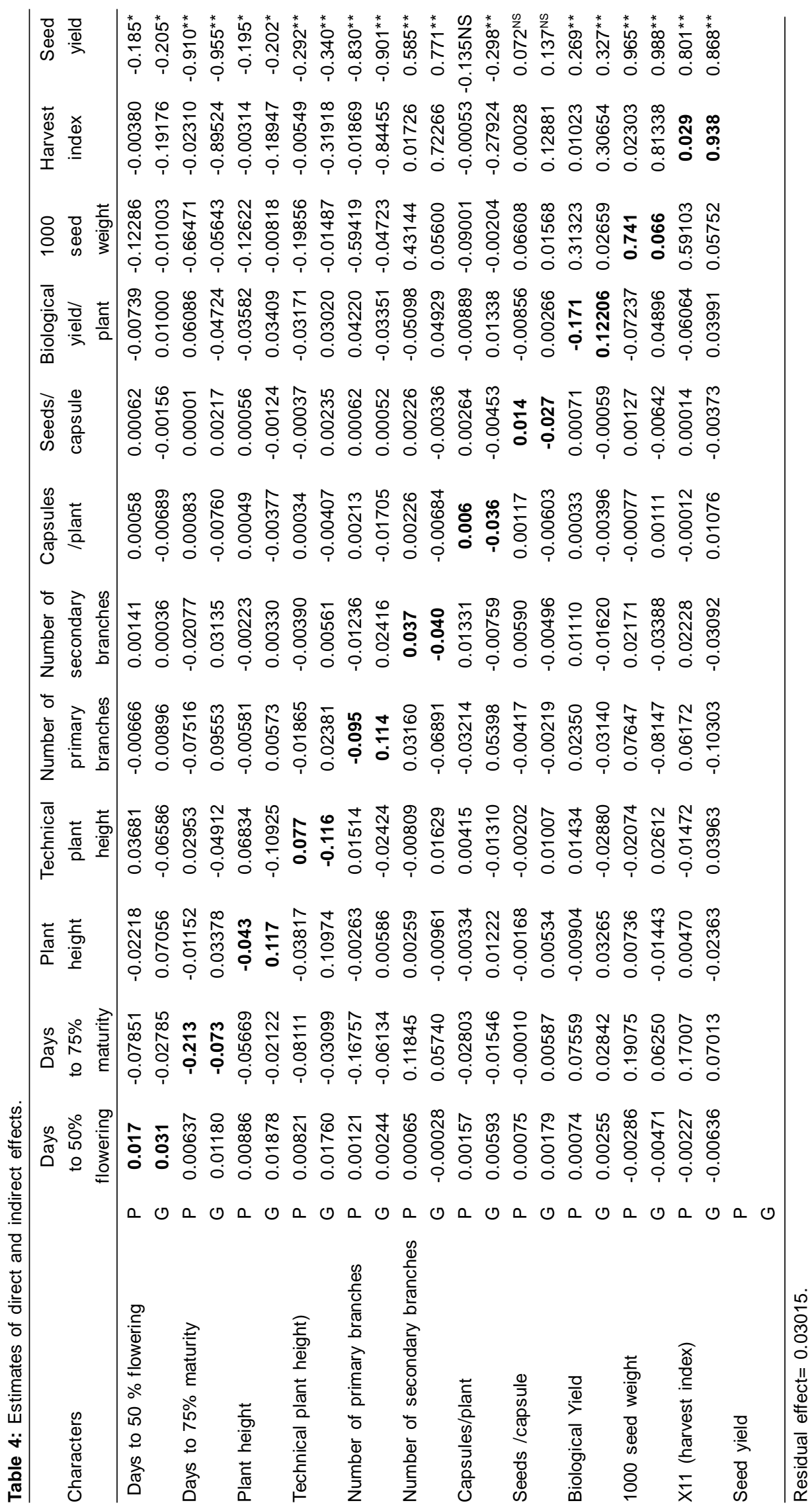


two characters. Significant positive correlation between the two traits may also be due to pleiotropic effects i.e., a single gene governs the expression of two traits. Hence, increase in the value of one will also increase the value of other.

\section{Path coefficient analysis}

Path analysis differs from simple correlation in that it points out the causes and their relative importance, whereas latter simply measures the mutual association ignoring the causation. Therefore characters association were partitioned into direct and indirect effects as given in (Table 4). The positive correlation with seed yield was observed for characters 1000 seed weight, harvest index, secondary branches and biological yield. The path coefficient analysis on phenotypic level revealed that 1000 seed weight exhibited maximum positive direct effect with seed yield $(0.741)$ while others had a low direct effect indicating that seed yield can't be improved by selecting these characters. However, the significant positive correlation of number of secondary branches and harvest index with seed yield was mainly due to indirect effect via 1000 seed weight This specifies that 1000 seed weight is the most imperative trait for the improvement of grain yield whereas, selection for number of secondary branches and harvest index would also have a positive indirect effect on seed yield. Therefore, these characters could be considered important during selection for advancement of grain yield. Other characters had negligible or very low direct and indirect effects on seed yield. The present investigation is in agreement with Badwa, et al. (1970), Ahmad (2017), Gudmewad et al.(2018) who also reported that 1000 seed weight is one of the major factors which directly contribute to seed yield. The residual effect was found to be low (0.03015) indicating that the causal factors account for the variability of the dependent factor i.e. seed yield in the present case.

\section{CONCLUSION}

It is concluded from the results of this experiment that 1000 seed weight could be considered the major yield contributing character because it showed a highly positive significant correlation with seed yield at both phenotypic and genotypic level and also had the maximum positive direct effect on seed yield. While other traits like number of secondary branches and harvest index should also be given importance while designing new breeding programmes for linseed improvement.

\section{REFERENCES}

Ahmad, E. (2017). Genetic studies of yield and yield component of Linseed (Linumu sitatissimum L.). Journal of Pharmacognosy and Phytochemistry. 1: 872-875.

Akbar, M., Khan, N.U.I. and Sabir, K.M. (2001). Correlation and path coefficient studies in linseed. Online Journal of Biological Sciences. 1: 446-447.

Ankit, K.S., Singh, S.P., Singh, V.K., Tiwari, A. and Singh, A. (2019). Estimation of genetic variability, heritability and genetic advance among the genotypes/lines for seed yield and other economic traits in linseed (Linum usitatissimum L.). Journal of Pharmacognosy and Phytochemistry. 8: 390-394.
Badwal, S.S., Gill, K.S. and Singh, H. (1970). Path coefficient analysis of seed yield in linseed. Indian Journal of Genetics. 30: 551-556.

Bhateria, S., Sood, S.P. and Pathania, A. (2006). Genetic analysis of quantitative traits across environments in linseed (Linum usitatissimum L.). Euphytica. 150: 185-194.

Burton, G.W., Devane, E.H. (1953). Estimating heritability in tall fescue (Festuca arundinaceia) from replicated clonal material. Agronomy Journal. 45: 478-481.

Cheverud, J.M. (1984). Quantitative genetics and developmental constraints on evolution by selection. Journal of Theoretical Biology. 110: 155-171.

Dabalo, D.Y., Singh, B.C.S. and Weyessa, B. (2020). Genetic variability and association of characters in linseed (Linum usitatissimum L.) plant grown in central Ethiopia region. Saudi Journal of Biological Sciences. 27: 2192-2206.

Dewey, D.R., Lu, K.H. (1959). A correlation and path coefficient analysis of components of crested wheat grass seed production. Agronomy Journal. 51: 515-518

Food and Agriculture Organization of the United Nations. (2019). http://www.FAOstat.fao.org.com

Gudmewad, R.B., Misal, A.M., Ghodke, M.K. and Dhuppe, M.V. (2018). Genetic and association studies in Linseed (Linum utitatissimum L.). Journal of Genetics Genomics and Plant Breeding. 2: 7-14.

Gudmewad, R.B., Khandagale, S.G. and Swamy, R.V. (2016). Correlation and path coefficient analysis of economically important traits in linseed (Linum usitatissimum L.) germplasm. Electronic Journal of Plant Breeding. 7: 427-433.

Ibrar, D., Ahmad, R., Mirza, M.Y., Mahmood, T., Khan, M.A. and lqbal, M.S. (2016). Correlation and path analysis for yield and yield components in linseed (Linum usitatissimum L.). Journal of Agricultural Research. 54: 153-159.

Johnson, H.W., Robinson, H.F. and Comstock, R.E. (1955). Estimates of genetic and environmental variability in soybean. Agronomy Journal. 47: 314-318.

Kumar, N. and Paul, S. (2016). Selection criteria of linseed genotypes for seed yield traits through correlation, path coefficient and principal component analysis. The Journal of Animal and Plant Sciences. 26: 1688-1695.

Millam, S., Obert, B. and Pret'ová, A. (2005). Plant cell and biotechnology studies in Linum usitatissimum: A review. Plant cell, Tissue and Organ Culture. 82: 93-103.

Patial, R., Paul, S. and Sharma, D. (2018). Correlation and path coefficient analysis for improvement of seed yield in linseed (Linum usitatissimum L.). International Journal of Current Microbiology and Applied Sciences. 7: 1853-1860

Rajanna, B., Biradar, S.A. and Ajithkumar, K. (2014). Correlation and path coefficient analysis in linseed (Linum usitatissimum L.). The Bioscan 9: 1625-1628.

Reddy, M.P., Reddy, B., Arsul, B.T. and Maheshwari, J.J. (2013). Character association and path coefficient studies in linseed. International Journal of Current Microbiology and Applied Sciences. 9: 25-254.

Sharma, D., Paul, S. and Patial, R. (2016). Correlation and path coefficient analysis of seed yield and yield related traits of linseed (Linum usitatissimum L.) in mid-hills of NorthWest Himalayas. The Bioscan. 11: 3049-3053. 
Studies on Correlation and Path Analysis in Linseed (Linum usitatissimum L.) Over Locations in Mid-hills of North - Western Himalayas

Singh, A., Rai, P.K., Kumar, A., Marker, S. and Yadav, P.K. (2015). Study on variability, heritability and correlation coefficient among linseed (Linum usitatissimum L.) genotypes. Advances in Applied Science and Research. 6: 14-17.

Slinkard, A.E., Solh, M.B. and Vandenberg, A. (2000). In: Linking Research and Marketing Opportunities for Pulses in the $21^{\text {st }}$ Century. Breeding for Yield: The Direct Approach. Springer, Dordrecht. pp. 183-190.

Sodini, S.M., Kemper, K.E., Wray, N.R. and Trzaskowski, M. (2018). Comparison of genotypic and phenotypic correlations: Cheverud's conjecture in humans. Genetics. 209: 941-948

Staistical Year Book of Himachal Pradesh. (2018). Economics and Statistics Department H.P. Shimla. https://himachal services. nic.in /economics/pdf/StatisticalYearBook_2019_20.pdf.
Tadesse, T., Singh, H. and Weyessa, B. (2009). Correlation and path coefficient analysis among seed yield traits and oil content in Ethiopian linseed germplasm. International Journal of Sustainable Crop Production. 4: 8-16.

Tariq, M.A., Hussain, T., Ahmad, I., Saghir, M., Batool, M., Safdar, M. and Tariq, M. (2014). Association analysis in linseed (Linum usitatissimum L.). Journal of Biology, Agriculture and Healthcare. 4: 60-62.

Terfa, G.N. and Gurmu, G.N. (2020). Genetic variability, heritability and genetic advance in linseed (Linum usitatissimum $\mathrm{L}$ ) genotypes for seed yield and other agronomic traits. Oil Crop Science. 5: 156-160. 